\title{
PEREMPUAN DAN PENDIDIKAN: REFLEKSI ATAS PENDIDIKAN BERPERSPEKTIF GENDER
}

\author{
Ana Rosilawati \\ Fakultas Tarbiyah dan Ilmu Keguruan (FTIK) \\ Institut Agama Islam Negeri (IAIN) Pontianak
}

\begin{abstract}
Education is a significant aspect which uses gender paradigm as a analytical tool to portray the women existence, especially in $t$

he equality and the equity values. Furthermore, the using of gender paradigm in an education world concerns on the equal opportunity given among men and women. This effort begins with the constructive process on differential behavior to women. Moreover, the weakness of women is identically considered as a 'kodrat'. Therefore, the writing is a critical reflection to the reality life of women in education world.
\end{abstract}

\section{Keywords:}

Woman, Education, Gender

\section{PENDAHULUAN}

Di awal tahun 1990-an, dunia informasi di Indonesia disemarakkan dengan kehadiran isu gender. Berbagai kajian, baik dalam bentuk tulisan maupun kegiatan ilmiah seperti seminar dan penelitian, dilakukan oleh banyak tokoh pemikir dengan berbagai disiplin ilmu mereka masingmasing. Demikian pula berbagai organisasi kemasyarakatan yang ikut menyibukkan diri dengan kegiatan-kegiatan bertemakan gender dan perempuan. Bahkan, kehadiran isu gender telah menjadi inspirasi bagi terbentuknya beberapa organisasi yang menjadikan penyelamatan nasib kaum perempuan sebagai tema pergerakan dan perjuangannya.

Persoalan di seputar kehidupan kaum perempuan, seperti : kesetaraan hak, pembedaan perlakuan, kekerasan dalam rumah tangga, tenaga kerja wanita perdagangan perempuan, merupakan tema-tema yang memadati perbincangan tentang gender. Tema-tema ini mendominasi pembicaraan di setiap kajian gender yang dilakukan, seakan kehadiran isu gender menjadi dewi penyelamat bagi kaum perempuan (Showalter, 1989: 5). Walaupun sebenarnya gender tidak hadir hanya dengan muatan tema keperempuanan, karena persoalan di seputar kehidupan kaum laki-laki juga ikut menghiasi pemikiran dan kajian gender, khususnya yang terkait dengan relasi kehidupannya dengan kaum perempuan.

Sebagai bentuk kajian yang mengkristal menjadi sebuah paradigma baru, gender kemudian digunakan untuk memotret berbagai realitas kehidupan, selama di dalam realitas dimaksud didapati kaum perempuan dengan persoalan status dan perlakuan terhadapnya. Persoalan yang muncul ketika kehadiran kaum perempuan dalam berbagai aspek kehidupan seperti, politik, budaya dan pendidikan, diidentikkan dengan perlambang 'kelemahan' sebagai konsekwensi kudrati dari realitas 'makhluk kedua', menjadi tema kritik yang intensif dan selalu dikedepankan (Lily, 1999: 5).

Pendidikan merupakan salah satu aspek penting kehidupan yang ikut mempergunakan paradigma gender sebagai pisau analisis dalam mengkaji eksistensi (keberadaan) kaum perempuan, terkait dengan nilai-nilai kesetaraan dan persamaan perlakuan. Penggunaan paradigma gender dalam dunia pendidikan lebih diarahkan pada upaya pemberian kesempatan yang sama antara perempuan dan laki-laki. Upaya ini diawali dengan proses pembongkaran atas sebab-sebab bagi telah terjadinya pembedaan perlakuan terhadap perempuan, dimana 'kelemahan' senantiasa diidentikkan sebagai karakteristik kudrati baginya. Identifikasi ini terlahir dari pembiasaan yang dijadikan perlakuan keseharian dalam rumah tangga. Pekerjaan keseharian yang diklasifikasi dengan tanpa dasar logis yang jelas, sebagai aktivitas feminis, seperti mencuci, memasak, menata rumah, merupakan pekerjaan yang dilekatkan pada peran perempuan. Sementara, pekerjaan yang 
dipahamkan sebagai aktivitas maskulin, seperti : bertukang, memperbaiki peralatan elektronik, dan menimba air, diidentikkan sebagai pekerjaan laki-laki.

Tanpa disadari, di dalam proses pendidikan formal, seorang guru sering melakukan pembedaan seperti tersebut di atas, seperti : lebih memilih siswa laki-laki untuk membantunya menggeser meja dan kursi kantor dari pada siswa perempuan. Sebaliknya, seorang guru sudah terbiasa meminta pertolongan siswa perempuan untuk membersihkan dan menata ruang kantor, demikian pula dengan membuatkan minuman untuk guru, daripada siswa laki-laki. Pembedaan perlakuan seperti ini sudah barang tentu akan memberikan pengaruh mental terhadap kebiasaan keseharian yang terbangun dalam diri guru dan siswa nantinya. Bisa jadi, perkembangan mental siswa yang hingga saat ini masih dirasakan berbeda antara laki-laki dan perempuan, merupakan salah satu konsekwensi logis dari pola perlakuan yang ditemukannya, baik dalam lingkungan pendidikan keluarga maupun di sekolah. Perbedaan dimaksud bisa diamati dari dominasi penetapan cita-cita masa depan mereka.

Paparan di atas telah mengusik daya tarik penulis untuk mengungkapnya dalam bentuk tulisan ilmiah. Dengan menjadikan 'Perempuan dan Pendidikan, Refleksi atas Pendidikan Berperspektif Gender' sebagai tema dalam tulisan ini, penulis berupaya melakukan refleksi kritis atas realitas keseharian perempuan dalam dunia pendidikan.

\section{JENIS KELAMIN (SEX) VERSUS GENDER}

Konsep penting yang harus dipahami ketika berbicara tentang sosialisasi gender adalah memisahkan dua konsep utama yaitu jenis kelamin dan gender. Dengan membedakan kedua konsep yang sering disalahfahami ini maka diharapkan para orang tua dan guru mengetahui mana sesungguhnya yang kodrati dan yang bukan kodrati bagi laki-laki dan perempuan.

Jenis kelamin merupakan pensifatan atau pembagian dua jenis kelamin manusia yang ditentukan secara biologis. Misalnya, bahwa manusia yang berjenis kelamin laki-laki memiliki penis, jakala dan memprodusi sperma. Sedangkan manusia yang berjenis kelamin perempuan memiliki alat reproduksi seperti rahim dan saluran untuk melahirkan, memproduksi telur, memiliki vagina dan alat menyusui. Secara biologis, semua yang disebutkan di atas melekat selamanya pada manusia yang berjenis kelamin laki-laki dan perempuan. Artinya, secara biologis, semua yang dimiliki dan melekat pada manusia jenis kelamin laki-laki tidak akan bisa dipertukarkan pada manusia jenis kelamin perempuan, begitu pula sebaliknya. Inilah yang dinamakan ketentuan Tuhan yang bersifat kodrati.

Sedangkan gender adalah suatu sifat yang melekat pada kaum laki-laki dan perempuan yang dikonstruksi secara sosial maupun kultural. Misalnya, bahwa perempuan dikenal sebagai makhluk yang lemah lembut, emosional dan keibuan. Sementara laki-laki dianggap sebagai makhluk yang memiliki fisik kuat, rasional, jantan dan perkasa. Ciri dari sifat ini sendiri sebenarnya merupakan sifat-sifat yang dapat dipertukarkan. Artinya, ada laki-laki yang emosional, lemah lembut dan keibuan, sementara ada juga perempuan yang kuat, perkasa, dan lebih mengedepankan rasio daripada emosionalnya. Perubahan ciri dari sifat tersebut dapat terjadi dari waktu ke waktu, dari suatu tempat ke tempat yang lain, dan inilah yang dinamakan sesuatu yang bukan kodrati ${ }^{14}$.

Contoh konkrit dari pemahaman gender di atas dapat dilihat dalam kehidupan masyarakat di Indonesia. Misalnya, dalam masyarakat yang sistem patriarkhi, meletakkan laki-laki sebagai penguasa dan pengambil kebijakan, sedangkan kaum perempuan tidak memiliki akses yang signifikan dalam semua lini kehidupan. Mereka ditempatkan sebagai subordinasi laki-laki, karena dianggap sebagai the second sex, sehingga mereka juga harus ditempatkan sebagai the second class. ${ }^{15}$

${ }^{14}$ Lihat Mansour Fakih, Analisis Gender dan Transformasi Sosial, Yogyakarta : Pustaka Pelajar, 2001), 7-9. Lihat juga Nasaruddin Umar, Argumen Kesetaraan Gender : Perspektif al-Quran (Jakarta: Paramadina, 1999), 33-36, dan Nurul Agustina \& Lies Marcoes, Gender, Jilid 6,7, ed. Taufik Abdullah (Jakarta: Ichtiar Baru Van Hoeve, t.t.), 175.

${ }^{15}$ Lihat Nikmatullah dkk, Relasi Gender dalam Tradisi Masyarakat Pesantren di NTB (Mataram: PSW STAIN Mataram, 2004), 12. 
Gambaran perempuan Sasak, Jawa, Makasar dan lainnya dapat mewakili potret perempuan yang lemah (dilemahkan).

Adapun masyarakat penganut sistem matriarkhi, mereka meletakkan perempuan sebagai pengambil kebijakan dan bahkan sebagai penguasa dalam keluarga dan masyarakat. Dalam hal ini, suku Minangkabau ${ }^{16}$ dapat diangkat sebagai potret perempuan yang dominan. Ini berarti bahwa pada waktu tertentu perempuan dapat lebih kuat dari laki-laki dan pada waktu yang lain menjadi "jajahan" laki-laki. Kondisi seperti ini sangat tergantung pada tempat, situasi dan kondisi zaman. Dalam tabel berikut dapat dilihat secara jelas perbedaan antara jenis kelamin dan gender

\begin{tabular}{|c|c|c|}
\hline $\mathrm{No}$ & Jenis Kelamin (Sex) & Gender \\
\hline 1. & $\begin{array}{l}\text { Merupakan perbedaan biologis antara } \\
\text { laki-laki dan perempuan }\end{array}$ & $\begin{array}{l}\text { Merupakan perbedaan peran, hak, } \\
\text { kewajiban kuasa dan kesempatan } \\
\text { antata lakia-laki dan perempuan } \\
\text { dalam kehidupan sosial }\end{array}$ \\
\hline 2. & $\begin{array}{l}\text { Perbedaan sex sama di seluruh dunia } \\
\text { bahwa perempuan menstruasi, } \\
\text { mengandung, melahirkan dan } \\
\text { menyusui, sementara laki-laki tidak, } \\
\text { sifatnya universal. }\end{array}$ & $\begin{array}{l}\text { kemasyarakatan. } \\
\text { Gender tidak sama di seluruh dunia, } \\
\text { tergantung dari kultur dan } \\
\text { perkembangan masyarakat di suatu } \\
\text { wilayah, sifatnya lokal. }\end{array}$ \\
\hline 3. & $\begin{array}{l}\text { Perbedaan sex tidak pernah berubah } \\
\text { dari waktu ke waktu. Dari dulu sampai } \\
\text { sekarang dan masa yang akan datang, } \\
\text { laki-laki tidak akan bisa menstruasi, } \\
\text { hamil, melahirkan dan menyusui. }\end{array}$ & $\begin{array}{l}\text { Gender berubah dari waktu ke } \\
\text { waktu., dari suatu tempat ke tempat } \\
\text { lainnya, dari suatu class ke class } \\
\text { yang lain. }\end{array}$ \\
\hline
\end{tabular}

Menurut Mansour Fakih (2001 : 9), sejarah munculnya perbedaan gender antara laki-laki dan perempuan terjadi melalui proses yang sangat panjang. Perbedaan-perbedaan tersebut kemudian dibentuk, disosialisasikan, diperkuat, bahkan dikonstruksi secara sosial dan kultural melalui ajaran keagamaan (tafsir keagamaan) dan negara. Melalui proses yang panjang, sosialisasi perbedaan gender tersebut akhirnya dianggap sebagai ketentuan Tuhan, seolah-olah bersifat biologis, tidak bisa diubah, sehingga kemudian perbedaan-perbedaan gender dipahami sebagai kodrat laki-laki dan kodrat perempuan. Lebih lanjut Mansour Fakih (2001 : 12) mengatakan bahwa "Perbedaan gender sesungguhnya tidak menjadi masalah sepanjang tidak melahirkan ketidakadilan gender. Namun yang menjadi persoalan ternyata perbedaan gender telah melahirkan berbagai ketidakadilan, baik bagi kaum laki-laki dan terutama terhadap kaum perempuan".

Dampak yang dimaksud dapat dilihat dalam beberapa manifestasi ketidakadilan gender (Mansour Fakih, 2000 : 46-48) sebagai berikut :

1. Marginalisasi atau proses pemiskinan ekonomi terhadap kaum perempuan. ${ }^{17}$

16 Perempuan di Minangkabau memiliki peran dan tugas sebagai kepala ruah tangga, mewarisi tanah, tiang utama ekonomi masyarakat, hasil jerih payah mereka secara langsung menjadi harta yang diwariskan dan menjaga keutuhan klan (yakni suatu pengelompokan social yang ditentukan berdasarkan silsilah keluarga perempuan). Sedangkan laki-laki memegang kendali semua urusan social masyarakat dan dipilih atas dasar kehormatan dan ketinggian reputasi klannya. Tidak mengherankan jika kemudian banyak laki-laki Minangkabau yang pergi meninggalkan kampung halamannya secara sukarela bahkan mengasingkan diri sebagai akibat ketidakberdayaan mereka untuk mengatur urusan ekonomi. Lihat Askiah Adam, "Islam dan Hak-hak Perempuan: Perspektif Asia Tenggara” dalam Menakar “Harga” Perempuan (Bandung: Mizan, 1999), 41.

${ }^{17} \mathrm{Hal}$ ini dapat dilihat dari adanya pertukaran peran dari perempuan petani yang kemudian digeser dengan munculnya alat-alat pertanian modern yang diasosiasikan dengan keahlian laki-laki. Selain itu adanya ketentuan yang melarang perempuan untuk bekerja pada malam hari, sehingga berakibat pada penurunan income yang akan didapatkan oleh perempuan. 
2. Subordinasi atau anggapan tidak penting dalam keputusan politik.

3. Pembentukan stereotype ${ }^{18}$ atau pelabelan negatif.

4. Kekerasan (violence), baik secara fisik ${ }^{19}$ maupun non fisik ${ }^{20}$.

5. Beban kerja yang panjang dan lebih banyak (burden $)^{21}$

Bentuk-bentuk ketidakadilan gender tersebut di atas tidak bisa dipisahkan, karena saling berkaitan dan berhubungan secara dialektis. Misalnya, marginalisasi ekonomi kaaum pwerempuan menyebabkan kekerasan, yang akhirnya tersosialisasikan dalam keyakinan dan visi kaum perempuan sendiri. Karenanya, agar peran perempuan dapat dimaksimalkan, pemahaman tentang gender mutlak diperlukan. Kesetaraan dan keadilan gender merupakan syarat mutlak untuk menciptakan tatanan masyarakat yang adil dan manusiawi. Oleh karenanya, tidak benar anggapan yang mengatakan bahwa gerakan kesetaraan dan keadilan gender itu merupakan upaya merusak tatanan masyarakat yang telah baku. Yang benar adalah, kesetaraan dan keadilan gender menciptakan tatanan masyarakat yang adil dan manusiawi.

\section{PENDIDIKAN BERPERSPEKTIF GENDER}

Pendidikan berperspektif gender merupakan salah satu dari sekian banyak tema yang terlahir dari rahim pergerakan kaum perempuan. Pergerakan dimaksud selanjutnya terkristalisasi dalam wujud sebuah paham keperempuanan yang biasa diistilahkan dengan “feminisme'. Feminisme merupakan produk pemikiran kaum perempuan di London yang merasa lelah diperlakukan tidak adil oleh tradisi patriarchal (berpihak pada laki-laki) (Hewitt, 1995 : 15).

Pada awalnya, kehadiran pergerakan ini dicemooh oleh banyak kalangan yang merasa terusik oleh beberapa bentuk kritikan yang disuarakan oleh feminisme. Uniknya, kelompok yang mencemoohkan dan bersikap antipati terhadap pergerakan kaum perempuan ini justru dominan dari kalangan perempuan sendiri (Wolf, 1997 : 99). Akan tetapi, setelah realitas kehidupan mampu membuktikan keberhasilan dari eksistensi (keberadaan) kaum perempuan, kehadiran feminisme dengan kandungan tema gender di dalamnya, mendapatkan respon positif dan sangat diminati.

Pendidikan, sebagai aspek penting dalam kehidupan, merupakan lahan subur bagi pembiakan tema gender. Dalam proses pendidikan, tema ini tidak hanya sekedar dikaji dalam dataran teoritis, akan tetapi juga dituntut untuk dapat diterapkan secara konkret (Salam Riningsih, 2000 : 25). Pola prilaku yang tidak membedakan antara siswa perempuan dengan siswa laki-laki, tentunya akan menjadi penguat bagi keberhasilan penerapan pendidikan berspektif gender.

\section{Makna Pendidikan Berperspektif Gender}

Pendidikan berperspektif gender dimaksudkan dengan pendidikan yang mengedepankan persamaan pemaknaan perhatian, dan perlakuan terhadap siswa, antara perempuan dan laki-laki. Persamaan tersebut diaplikasikan dalam semua aktivitas di lingkungan pendidikan, baik di lingkungan keluarga maupun di lingkungan sekolah. Di samping itu, penyamaan juga dilakukan dalam segala hal dengan tidak membedakan atau memihakkan aktivitas kepada jenis kelamin tertentu. Pendidikan berperspektif gender juga

18 Stereotype yang dimaksud adalah citra baku tentang individu atau kelompok yang tidak sesuai dengan kenyataan empiris. Hal ini mengakibatkan terjadinya diskriminasi dan berbagai ketidakadilan yang merugikan, khususnya bagi kaum perempuan.

${ }_{19}$ Seperti perkosaan, pemukulan dan penyiksaan

${ }^{20}$ Seperti pelecehan seksual yang mengakibatkan terusiknyaemosional sang korban.

${ }^{21}$ Ini terjadi karena anggapan dan kebijakan dari pemerintah yang menegaskan bahwa perempuan adalah ibu rumah tangga. Konsekwensinya adalah segala urusan domestic menjadi tanggung jawab perempuan. Apabila perempuan bekerja di luar umah, maka selain ia harus mengerjakan pekerjaan kantor, ia juga harus mengerjakan dan membereskan pekerjaan rumah. Ini disebabkan anggapan bahwa pekerjaan rumah adalah tanggung jawab utama bagi sang isteri, sedangkan pekerjaan di luar rumah adalah bentuk bantuan isteri kepada suami. Anggapan dankebijakan ini telahmenyebabkan perempuan harus bekerja ganda dan menghabiskan waktu yang lebih panjang daripada laki-laki. Bahkan perempuan bekerja dari terbit matahari sampai terpejamnya mata suami. 
diartikan sebagai sebuah pola pendidikan yang lebih mengedepankan penghargaan dan penilaian atas prestasi individu dengan tanpa membedakan jenis kelamin siswa. Hal ini didasarkan pada pemahaman bahwa setiap individu memiliki kemampuan dan potensi yang berbeda. Perbedaan dimaksud tidak disebabkan oleh perbedaan jenis kelamin, akan tetapi lebih disebabkan oleh kesempatan dan kesediaan pengembangan potensi kedirian siswa masing-masing. Pendidikan menjadi fasilitas yang berpotensi untuk melakukan pengembangan potensi kedirian siswa. Melalui pendidikan pula potensi yang dimiliki siswa dapat disalurkan menjadi sebuah harapan konkret dalam wujud pencapaian cita-cita.

Pendidikan berperspektif gender dapat pula diartikan sebagai pembiasaan untuk menghargai perbedaan sebagai sebuah kekuatan dalam relasi saling mengisi dan memberi. Pemaknaan seperti ini didasarkan pada pemahaman bahwa perbedaan, terutama perbedaan jenis kelamin, adalah sebuah kesejatian kudrati yang tidak terlahir dari kehendak manusia.

\section{Pendidikan Gender di Sekolah}

Keberhasilan dari pola pendidikan berspektif gender sangat bergantung pada keseriusan pelaku didik yang berwujud dalam pembiasaan keseharian aktivitas. Dalam lembaga pendidikan formal, keseriusan dapat dilihat dari bagaimana seorang guru merancang sebuah kelas yang tidak dilakukan dengan membedakan antara siswa perempuan dan laki-laki. Demikian pula dengan perancangan guru terhadap pemberian tugas kepada siswanya yang tidak memperhatikan pembedaan jenis kelamin siswanya. Hal ini bisa dilihat dari penetapan rancangan pembagian tugas dalam beberapa kegiatan ekstra kurikuler.

Pada bagian lain, pendidikan berperspektif gender dapat dilakukan melalui pembiasaan keseharian di lingkungan sekolah. Pemberian tugas tambahan kepada siswa, seharusnya tidak lagi didasarkan pada perbedaan jenis kelamin siswa, akan tetapi pada keinginan untuk menjalin ikatan emosional antara guru dengan siswanya.

Hal lain yang dapat dilakukan dalam pendidikan berspektif gender adalah dengan menukar kebiasaan yang sebelumnya diidentifikasi berdasar jenis kelamin. Penukaran pembiasaan ini bisa diwujudkan dengan memberikan tugas tertulis kepada siswa perempuan untuk menulis artikel tentang eksistensi (keberadaan) laki-laki, dan tema eksistensi (keberadaan) perempuan sebagai tugas tertulis bagi siswa laki-laki.

\section{Pendidikan Gender dalam keluarga}

Keluarga merupakan satuan sosial terkecil dalam kehidupan umat manusia. Dalam bentuk dan strukturnya yang paling mendasar, sebuah keluarga pada umumnya terdiri atas ayah, ibu dan anak-anak mereka yang biasa tinggal dalam satu rumah, yaitu rumah tangga. ${ }^{22}$ Menurut Ahmad Tafsir (1994 : 155), dalam pandangan Islam, keluarga atau rumah tangga merupakan lingkungan pertama dan utama bagi pertumbuhan dan perkembangan seseorang.

Untuk mencapai tujuan tersebut, maka orangtualah yang menjadi pendidik pertama dan utama. Kaidah ini ditetapkan secara kodrati, dimana orangtua tidak dapat menolaknya, dalam keadaan bagaimanapun juga. Mengapa demikian? Karena mereka ditakdirkan menjadi orangtua dari anak yang dilahirkannya. Dengan demikian, mau tidak mau, mereka harus menjadi penanggung jawab pertama dan utama. Kaidah ini diakui oleh semua agama dan semua sistem nilai yang dikenal oleh manusia. ${ }^{23}$

Dengan demikian, peran mendidik anak bukanlah mutlak kewajiban seorang ibu, tetapi juga ayah. Bahkan di dalam Al-Quran, banyak sekali kisah-kisah yang menceritakan besarnya peran

${ }^{22}$ Lihat Munandar Soelaeman, IImu Sosial Dasar: Teori dan Konsep Ilmu Sosial (Bandung: Refika Aditama, 1998), 56.

${ }^{23}$ Lihat juga Moh. Shochib, Pola Asuh Orang Tua dalam Membantu Anak dalam Mengembangkan Disiplin Diri (Jakarta: Rineka Cipta, 1998), 10. 
ayah dalam pendidikan anak. Contoh yang paling jelas adalah kisah Luqman $^{24}$ ketika memberi nasehat kepada anak-anaknya. Begitu pula kisah Nabi Sulaiman yang dididik ayahnya, Nabi Daud yang dididik khusus untuk menggantikan posisi ayahnya sebagai raja, atau Nabi Yusuf yang mendapat curahan kasih sayang dari Nabi Ya cub sehingga membuat iri saudara-saudaranya yang lain, merupakan kisah yang menceritakan besarnya peran ayah dalam pendidikan anak. Adapun Rasulullah sendiri, meskipun ditinggal oleh ayahnya sejak dalam kandungan, tapi peran sang ayah ini tergantikan oleh kakek dan pamannya yang mengasuh beliau sejak kecil. Kisah-kisah tersebut sangat jelas menggambarkan kepada kita peran sang ayah dalam pendidikan anak-anaknya. ${ }^{25}$

Dalam mendidik dan memperlakukan anak-anak, orang tua hendaknya tidak membedabedakan antara anak laki-laki dan perempuan. Orang tua harus berlaku adil kepada mereka dalam segala hal (Abdullah Nashih Ulwan, 1999 : 37-38), sebab anak merupakan amanat bagi orang tuanya. Sebagai amanat, baik buruknya perkembangan kepribadian, karakter, sikap dan tingkah laku anak, sangat bergantung kepada baik-buruknya pembiasaan yang diberikan kepadanya. Oleh karena itu, peran orang tua sangat dominan dalam membentuk kepribadian dan pendidikan anak dalam keluarga.

Peran orang tua yang dominan dalam mendidik anak di keluarga, memberikan peluang yang sangat besar bagi tersosialisasinya gender. Yang menjadi persoalannya adalah bahwa umumnya orang tua tidak memahami bahkan tidak mengetahui apa sesungguhnya yang dimaksud dengan gender dan dampak yang ditimbulkan oleh bias gender ${ }^{26}$ tersebut. Ketidaktahuan orang tua tersebut menyebabkan anak diajarkan, ditunjukkan, dan diberi peran atau tanggung jawab yang sesuai dengan yang dianggap sebagai kodrat laki-laki dan permpuan. Contoh konkritnya adalah seperti tugas perempuan itu bekerja dalam rumah, memasak, mencuci, membersihkan rumah, mendidik anak, menjahit, dan lain sebagainya. Sedangkan laki-laki bekerja di luar rumah, menjadi pemimpin keluarga, menyetir, membetulkan genteng, memanjat pohon, dan lain sebagainya.

\section{PERAN ORANGTUA DALAM SOSIALISASI}

Keluarga mempunyai peranan penting karena dipandang sebagai sumber pertama dalam proses sosialisasi. Keluarga juga berfungsi sebagai transmitter budaya, atau mediator sosial budaya bagi anak. Lebih dari itu, keluarga juga dipandang sebagai instansi yang dapat memenuhi kebutuhan insan, terutama kebutuhan bagi pengembangan kepribadiannya.

Melalui proses sosialisasi, seseorang akan terwarnai cara berpikir dan bertindaknya melalui kebiasaan-kebiasaan hidupnya. Dengan demikian, sosialisasi gender yang dilakukan oleh orangtua terhadap anak dalam keluarga akan mempengaruhi pola pikir dan persepsi anak tentang peran mereka dalam keluarga. Jika pola pikir dan persepsi mereka telah terbentuk, maka akan mudah bagi mereka untuk mewujudkannya dalam tingkah laku dan pola interaksi mereka.

Ada beberapa pola sosialisasi yang perlu ditempuh orangtua untuk menanamkan pemahaman tentang gender kepada anak, antara lain dengan :

1. Keteladanan

Orang tua harus memberikan keteladanan atau contoh kepada anak-anaknya. Anakanak akan meniru dan mengidentifikasi perilaku orang tua ke dalam diri mereka. Jika mereka selalu melihat aktivitas ibu selalu di dapur untuk memasak dan menghidangkan makanan, mencuci pakaian, menyapu dan merawat rumah, serta mengasuh anak, sedangkan aktivitas ayah bekerja di luar rumah, dibuatkan minuman, dilayani, pengambil keputusan dan lain sebagainya,

\footnotetext{
${ }^{24}$ Lihat surah Luqman/31: 13 - 19.

25 Tentu saja hal ini tidak terlepas dari tarbiyah Rabbaniyyah (pendidikan langsung dari Allah) mengingat tugastugas mereka sebagai Nabi dan Rasul.

${ }^{26}$ Bias gender adalah sebuah pandangan dan sikap yang lebih mengutamakan salah satu jenis kelamin daripada jenis kelamin lainnya sebagai akibat pengaturan dan kepercayaan budaya yang lebih berpihak kepada jenis kelamin tertentu, misalnya lebih berpihak kepada laki-laki daripada kepada perempuan atau sebaliknya. Sebagai contoh, pandangan atau sikap yang terlihat dalam gagasan-gagasan bahwa laki-laki itu lebih kompeten, lebih mampu, lebih superior daripada perempuan
} 
akan membentuk pola piker atau persepsi anak bahwa apa yang dilakukan oleh ibu dan ayahnya merupakan peran dan tanggung utama sebagai laki-laki dan persempuan.

Persepsi ini kemudian akan melekat dalam diri anak dan akan diterapkan kelak ketika mereka sudah dewasa dan berumah tangga. Pembakuan peran semacam ini akan terus berlangsung dan mengakar jika tidak dimulai dengan "reposisi peran" yang dapat dilakukan dengan membiasakan ayah ikut terlibat dalam urusan-urusan rumah tangga yang sudah biasa dilakoni seorang ibu. Begitu pula sebaliknya, seorang ibu dapat bergandengan tangan bersamasama ayah saling bahu membahu dalam menopang kehidupan keluarga.

Dengan demikian, anak-anak akan memiliki persepsi bahwa ruang privat/domestic bukan semata-mata urusan ibu dan ruang publik bukan urusan ayah belaka. Dengan keteladanan ini, anak secara tidak langsung akan memiliki persepsi bahwa laki-laki dan perempuan harus saling bahu membahu dan satu sama lain tisdak dapat terpisahkan. Pada akhirnya, persepsi semacam ini dapat menghindarkan terjadinya ketidakadilan yang ditimbulkan oleh bias gender tersebut.

2. Pembiasaan

Orangtua harus menanamkan kebiasaan-kebiasaan yang tidak diskriminatif terhadap anak laki-laki dan perempuan. Misalnya, membiasakan anak laki-laki dan perempuan untuk mengerjakan tugas-tugas domestik secara bersama-sama, membiasakan mereka bersikap lemah lembut, santun, bekerja keras untuk mencapai tujuan, disiplin, tidak cengeng, mandiri dan sebagainya. Jika pembiasaan yang diberikan kepada anak tidak diskriminatif, maka akan terbentuk pribadi-pribadi yang baik sehingga mampu berinteraksi dengan harmonis, karena pembiasaan yang mereka dapatkan dari keluarga telah mengilhami mereka untuk saling menghargai dan mengayomi satu sama lain.

Sebaliknya, jika mereka tidak dibiasakan dari kecil, mungkin mereka hanya tahu yang baik dan buruk, tapi tidak mampu melaksanakan yang baik dan meninggalkan yang buruk. Di sinilah pentingnya membiasakan hal-hal yang baik kepada anak sejak dini.

3. Mengajarkan pengetahuan tentang gender dan mendialogkan persoalan-persoalan yang terjadi akibat bias gender

Menanamkan pengertian gender kepada anak-anak sangat penting penting dilakukan orangtua, dan dialog merupakan cara yag paling tepat. Hal ini bisa dilakukan ketika berada di meja makan atau sedang berkumpul di ruang keluarga sambil menonton TV. Jika kebetulan acara yang ditonton menayangkan berita-berita mengenai ketidakadilan yang diterima oleh kaum perempuan seperti trafficking, perkosaan, penyiksaan suami kepada isteri, tenaga kerja wanita yang dieksploitasi dan tidak mendapat gaji, dan kasus-kasus yang lainnya, maka moment seperti ini menjadi sangat strategis untuk menularkan pemahaman tentang gender dan mendialogkan peristiwa-peristiwa yang sedang ditonton dengan memakai perspektif gender.

Orangtua dapat menjelaskan kepada anak bahwa laki-laki dan perempuan memiliki kedudukan yang sama di mata Allah, yang membedakan hanyalah ketakwaannya. Allah dengan tegas menyebutkan bahwa perbedaan secara biologis antara laki-laki dan perempuan, tidak dapat menentukan dan menjadi ukuran untuk melihat derajat seseorang. Bahkan Allah memerintahkan kepada laki-laki dan perempuan untuk sama-sama menyerukan dan mengajak kepada kebaikan dan mencegah kemunkaran. Mereka sama-sama mendapatkan pahala dan harus menanggung dosa dari kejahatan yang diperbuat. Dengan sharing pemahaman seperti ini dan mendialogkan kasus-kasus yang terjadi dengan perspektif gender, dapat membantu anak memahami tentang gender dan dampak yang ditimbulkan dari adanya bias gender.

4. Menyediakan bahan bacaan atau media lainnya yang berperspektif gender

Cara ini memang agak sedikit sulit karena biasanya buku, majalah, koran, VCD ataupun kaset, jarang sekali yang bersperspektif gender. Apalagi ditambah dengan buku-buku agama yang kebanyakan mengandung nuansa fiqh oriented, terkesan justru mendiskreditkan perempuan dan lebih mengutamakan laki-laki. Bahkan, buku-buku ajar yang menjadi 
pegangan para siswa banyak memuat rumusan kalimat, penjelasan dan gambar yang mencerminkan ketidaksetaraan gender.

Walaupun agak sulit, bukan berarti orangtua tidak bisa mengupayakannya. Justru seharusnya kondisi seperti ini memicu semangat orangtua untuk bisa mengatasi dan menyediakan media tersebut. Hal ini menjadi penting, karena media-media tersebut sangat efektif untuk dapat mempengaruhi cara pandang dan pola pikir anak.

Demikianlah beberapa pola yang menurut hemat penulis dapat diterapkan atau dilakukan dalam proses sosialisasi gender dalam keluarga. Dengan adanya pola-pola tersebut diharapkan dapat terwujud kesetaraan gender yang dibangun dan dimulai dari keluarga. Bukankah keluarga yang baik akan menciptakan masyarakat yang baik? Bukankah masyarakat yang baik dapat mewujudkan kondisi Negara yang baik pula? Kita semua tentu berharap semua itu dapat terwujud.

\section{PENUTUP}

Sebagai lembaga pendidikan, tentu saja keluarga dan sekolah dapat memberikan peluang yang sangat besar bagi tersosialisasinya gender. Banyak cara yang dapat ditempuh untuk proses sosialisasi tersebut, tetapi, banyak pula tantangan yang harus dihadapi. Untuk itu, kiranya kepada pihak-pihak yang berkompeten di bidang sosialisasi gender ini hendaknya berupaya semaksimal mungkin untuk menggeser nilai-nilai budaya yang mendiskreditkan perempuan.

Negara, dalam hal ini pemerintah, hendaknya menghapus segala bentuk peraturan yang merugikan perempuan dan menggantinya dengan peraturan atau kebijakan yang berkeadilan gender. Hal ini tentu saja sebagaimana yang diamanatkan dalam Konvensi Penghapusan Segala Bentuk Diskriminasi terhadap Perempuan (Konvensi CEDAW) yang sudah diratifikasi oleh Indonesia melalui Undang-undang No. 7 tahun 1986.

Para pihak yang berkompeten seperti Pusat Studi Wanita (PSW) atau lembaga-lembaga lainnya hendaknya dapat memberikan pemahaman tentang gender kepada orangtua, guru, bukan hanya ibu, tapi juga bapak secara bersama-sama, karena masalah gender, sekali lagi bukan hanya masalah perempuan, tetapi sekaligus menjadi masalah bagi laki-laki.

Para pemegang otoritas keagamaan yang sangat didengar petuah dan wejangannya, hendaknya dapat melakukan penafsiran secara kontekstual terhadap ayat-ayat Al-Quran, sehingga misi Islam mengangkat harkat dan martabat perempuan dapat terwujud. Terakhir, harus ada keberanian dari diri perempuan untuk merubah keadaan yang mempertahankan status quo dengan memulainya dari lingkungan keluarga, dan mempraktekkannya kepada anak-anak mereka.***

\section{REFERENSI}

Ahmad Tafsir, 1994, Ilmu Pendidikan dalam Perspektif Islam, Bandung: Remaja Rosdakarya.

Askiah Adam, 1999, Islam dan Hak-hak Perempuan: Perspektif Asia Tenggara dalam Menakar "Harga" Perempuan, Bandung: Mizan.

Budi Wahyuni, 1997, Terpuruk Ketimpangan Gender, Yogyakarta : LAPERA Pustaka Utama.

Gadis Arivia, ed. 2007, Perempuan untuk Perdamaian Indonesia, Seri Women for Peace, Jakarta : Filsafat UI Press.

Hewitt, Marsha Aileen, 1995, Critical Theory of Religion, A Feminist Analysis, Minneapolis : Fortress Press.

Illich, Ivan, 1998, Matinya Gender, Alih bahasa : Omi Intan Naomi, Yogyakarta : Pustaka Pelajar. 
Lily Zakaria Munir, ed., 1999, Memposisikan Kodrat, Perempuan dan Perubahan dalam Perspektif Islam, Bandung : Mizan.

Mansour Fakih, 2000, "Posisi Kaum Perempuan dalam Islam : Tinjauan dari Analisis Gender", dalam Membincang Feminisme, Surabaya: Risalah Gusti.

-------------, 2001, Analisis Gender dan Transformasi Sosial, Yogyakarta: Pustaka Pelajar.

Nikmatullah dkk, 2004, Relasi Gender dalam Tradisi Masyarakat Pesantren di NTB, Mataram: PSW STAIN Mataram.

Nurul Agustina \& Lies Marcoes, t.t., Gender, Jilid 6,7, ed. Taufik Abdullah, Jakarta: Ichtiar Baru Van Hoeve.

Rocky Gerung, ed. 2007, Kumpulan Esai Pelajar SMA, Seri Women for Peace, Jakarta : Filsafat UI Press.

Salam Riningsih, dkk. 2000, Praktek Deskriminasi terbadap Pendidikan Anak Perempuan, Laporan Penelitian.

Showalter, Elaine, ed. 1989, Speaking of Gender, New York : Routledge.

Wolf, Naomi, 1997, Gegar Gender, Kekuasaan Perempuan Menjelang Abad 21, Yogyakarta : Pustaka Semesta Press. 